\title{
Mineral content of grain yield of cereals and the effect of fertilization on it
}

\author{
Yrjö Pessi, Jorma Syvälahti, Esko SaAri and Mikko Ylänen \\ Kemira Oy, Helsinki
}

\begin{abstract}
This investigation examines the mineral content of cereal grain yields and the effect of NPK-fertilixation on this content. The NPK-fertilization and the increased yield level thus obtained have not essentially affected the mineral contents of cereal grain. Among different kinds of cereals the mineral content of oats is in most cases the highest and that of rye and winter wheat the lowest. None of the different kinds of fertilizers gave clear differences in the mineral content of barley grain.
\end{abstract}

\section{Introduction}

Several factors influence the quality of foodstuffs and feed. Cultivation techniques and soil factors are known to be important. The effect of fertilization on grain yield and on certain quality factors, such as protein and some minerals, has been known for a long time (SAUChelli 1969, GAUGH 1972). When minerals are added to soil, the content of these substances in plants has also increased. Most of these investigations give data on other plants than cereals, however, or on other parts of a plant than seed (e.g. KERÄNEN ant TAINIO 1969, BURRIDGE 1972).

The effect of fertilization on the mineral content of fruit and seed has been shown to be quite small in certain connections, whereas the effect has been stronger on the composition of leaves and other parts of a plant (ARNON 1966, GAUCH 1972).

Cereals as our basic foodstuffs are an important source of trace elements (KoIvistolnen 1971 and 1972). The purpose of this investigation was to investigate the amounts of some minerals in the grain of cereals and the effect of NPK-fertilization on their content.

\section{Materials and methods}

A total of 160 cereal samples were determined for their contents of ash, $\mathrm{N}, \mathrm{K}, \mathrm{P}, \mathrm{Ca}, \mathrm{Mg}, \mathrm{S}, \mathrm{Si}, \mathrm{Fe}, \mathrm{Mn}, \mathrm{Cu}, \mathrm{Zn}, \mathrm{Al}, \mathrm{Ni}, \mathrm{Cr}$ and most of the samples also for $\mathrm{Sr}$ and $\mathrm{B}$. Five kinds of cereals were represented in this investigation. The main part of the test material, however, consisted of spring wheat, barley 
and oats (Table 1). The samples were collected at the Kotkaniemi Experimental Farm in Vihti from various fertilizing tests in clay and sandy soils, and also at a former Experiment Station of the Society of Peat Cultivation at Leteensuo on Sphagnum peat during 1971 and 1972.

The average values of soil $\mathrm{pH}$ and the contents of certain nutrients extractable in acid ammonium acetate $(\mathrm{pH} 4.65)$ are as follows:

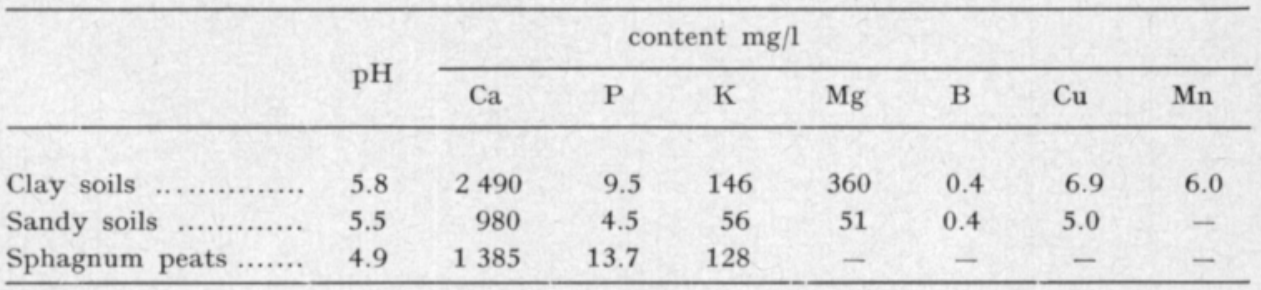

Analyses of the cereal samples were done in the following way: the grain samples were first ground in a Sako-mill (made by Falling Number Ab in Sweden). The meals were dried at $100^{\circ} \mathrm{C}$ over night and the actual analysis results were reported as dry weights. These samples were analyzed for phosphorus by the ammonium molybdate method, for nitrogen by the Kjeldahl method, for sulphur gravimetrically, for silicon by the silicomolybdate method and for boron by the carmine acid method. A Perkin-Elmer 403 atomabsorptionspectrophotometer was used in the determination of calcium, iron, manganese, zinc, aluminium, strontium, copper, nickel and chromium. For the atomabsorption determinations the samples were kept at $500^{\circ} \mathrm{C}$ over night after which nitric acid and perchloric acid were used to dissolve the samples. The analyzing was performed at the Oulu laboratory of Kemira Oy under the guidance of Messrs. Esko Saari and Arvo Paaso.

\section{Results and discussion}

Table 1 reports the average mineral content values of all the analyses on different kinds of cereals, their range of variation, the lowest and the highest values measured, the ash percentage and the yield. Among different kinds of cereals the contents of most minerals in oats (37 analyses) are in most cases the highest and those of rye ( 9 analyses) and winter wheat ( 5 analyses) the lowest. Especially should be noted the high contents of silicon, strontium, chromium and nickel in oats as compared to other cereals. This difference may be due to the large husk content of oats. Spring wheat (58 analyses) had on an average the highest $\mathrm{Mg}$-content and the lowest Sr-value. Barley contained plenty of iron and copper but less manganese than the other cereals.

Cereals grown in sandy soil were low in copper, and barley had also lower manganese and zinc values in sandy soil than in other kinds of soils. The iron, aluminium and copper contents of barley grown in peat soil proved to be especially high.

Fig. 1 presents the mineral content of spring wheat grown in clay soil at different levels of NPK-fertilization. It is significant that the potassium, 


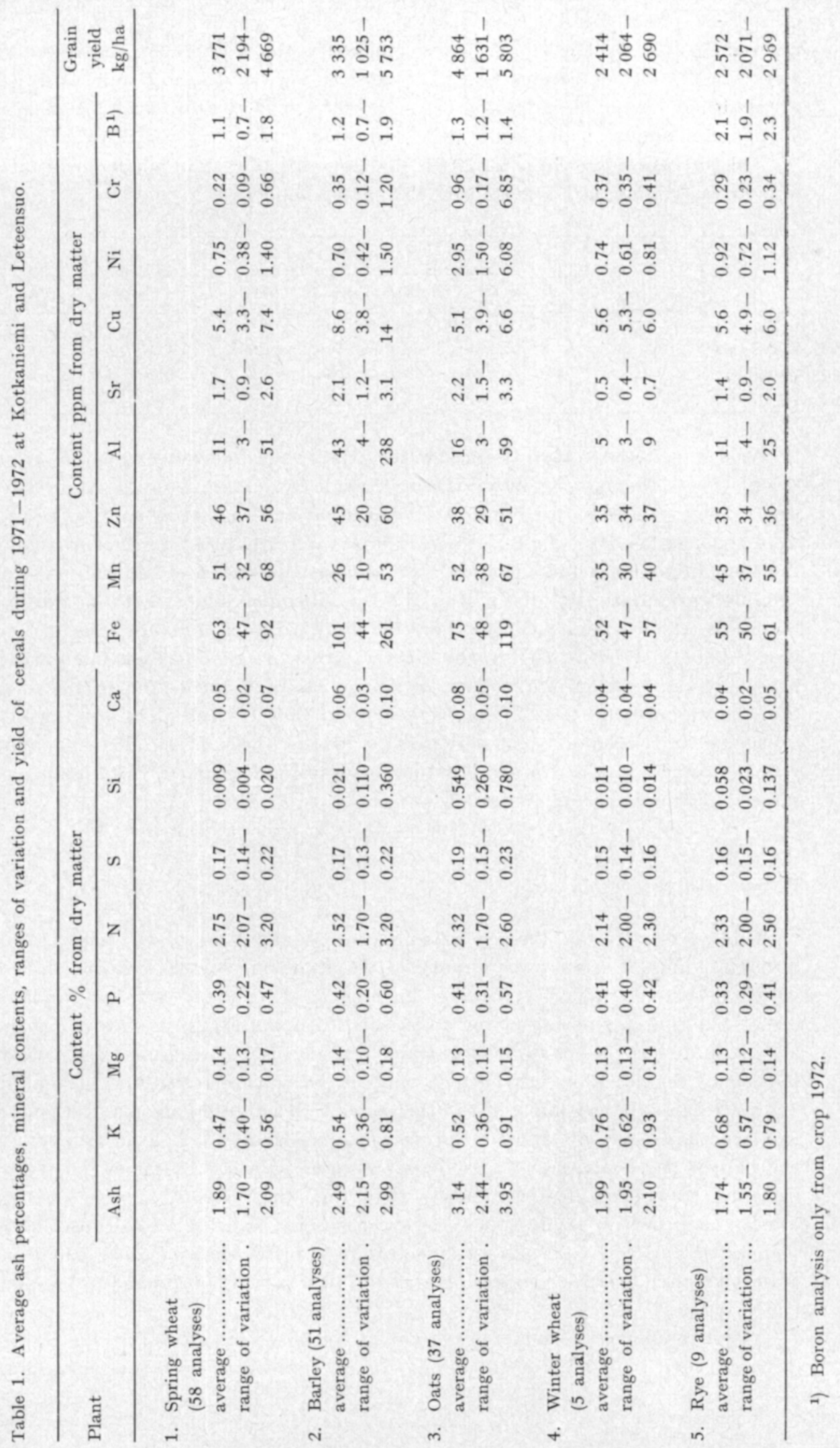




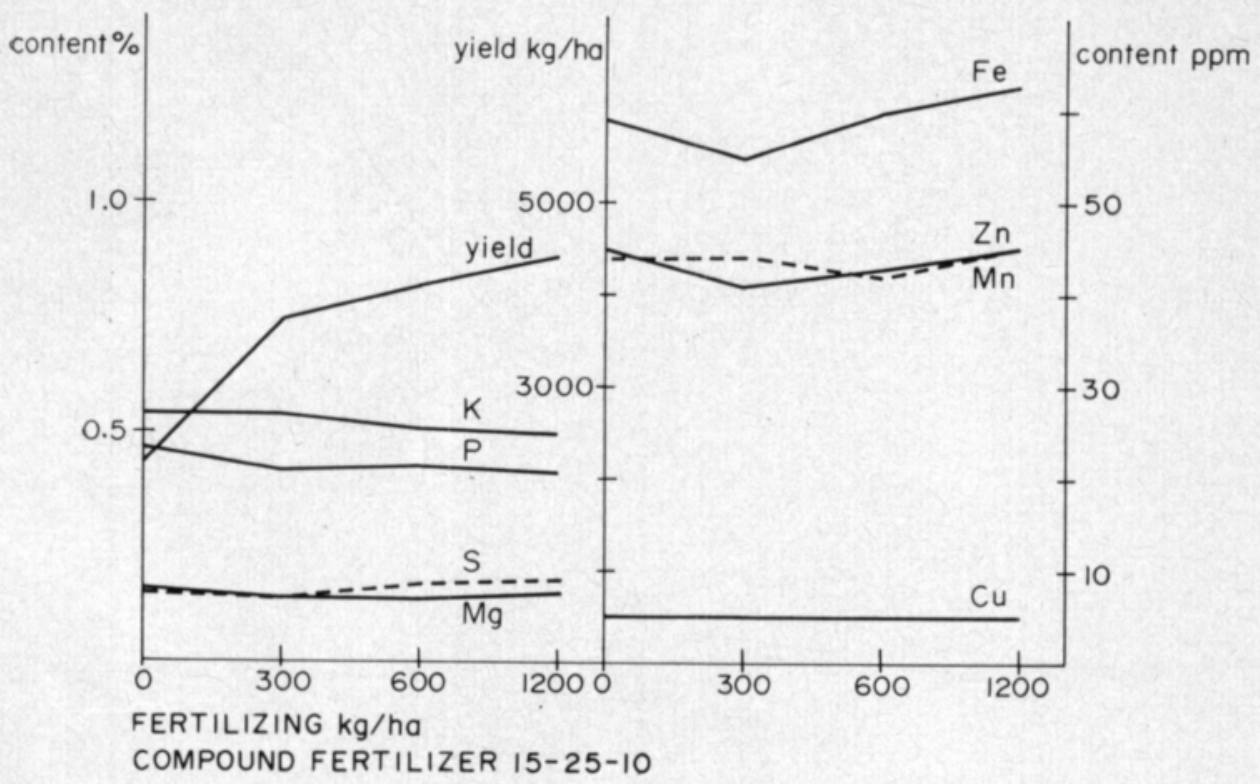

Fig. 1. Average contents of some minerals in spring wheat on dry weight basis and yield when grown in clay soil at Kotkaniemi during 1971 and 1972.

phosphorus, sulphur, magnesium, copper, manganese, zinc and iron contents do not become lower with an increase in the yield from $2190 \mathrm{~kg}$ to $4430 \mathrm{~kg}$ per hectare, due to NPK-fertilization. In the same way the concentration of minerals in barley, excluding zinc, has remained on almost the same level irrespective of NPK-fertilization (Fig. 2).

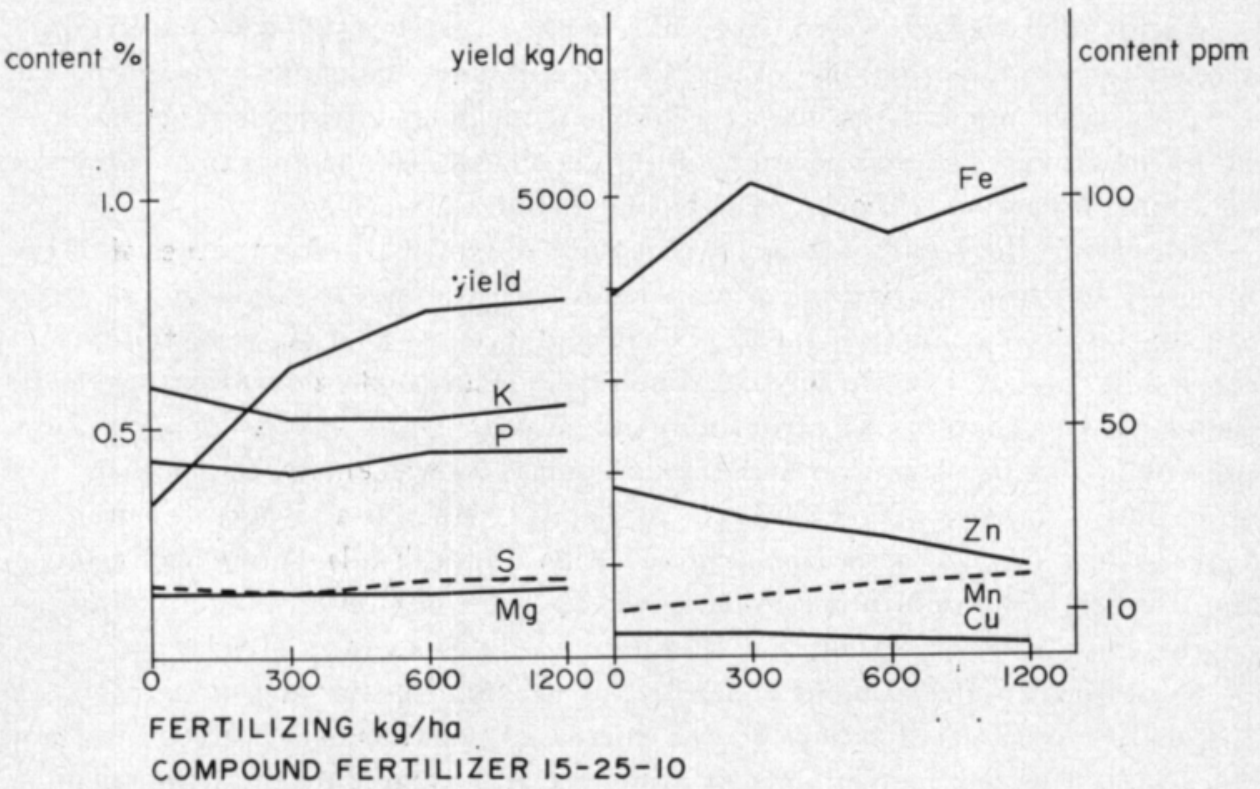

Fig. 2. Average contents of some minerals in barley on dry weight basis and yield when grown in sandy soil at Kotkaniemi during 1972. 


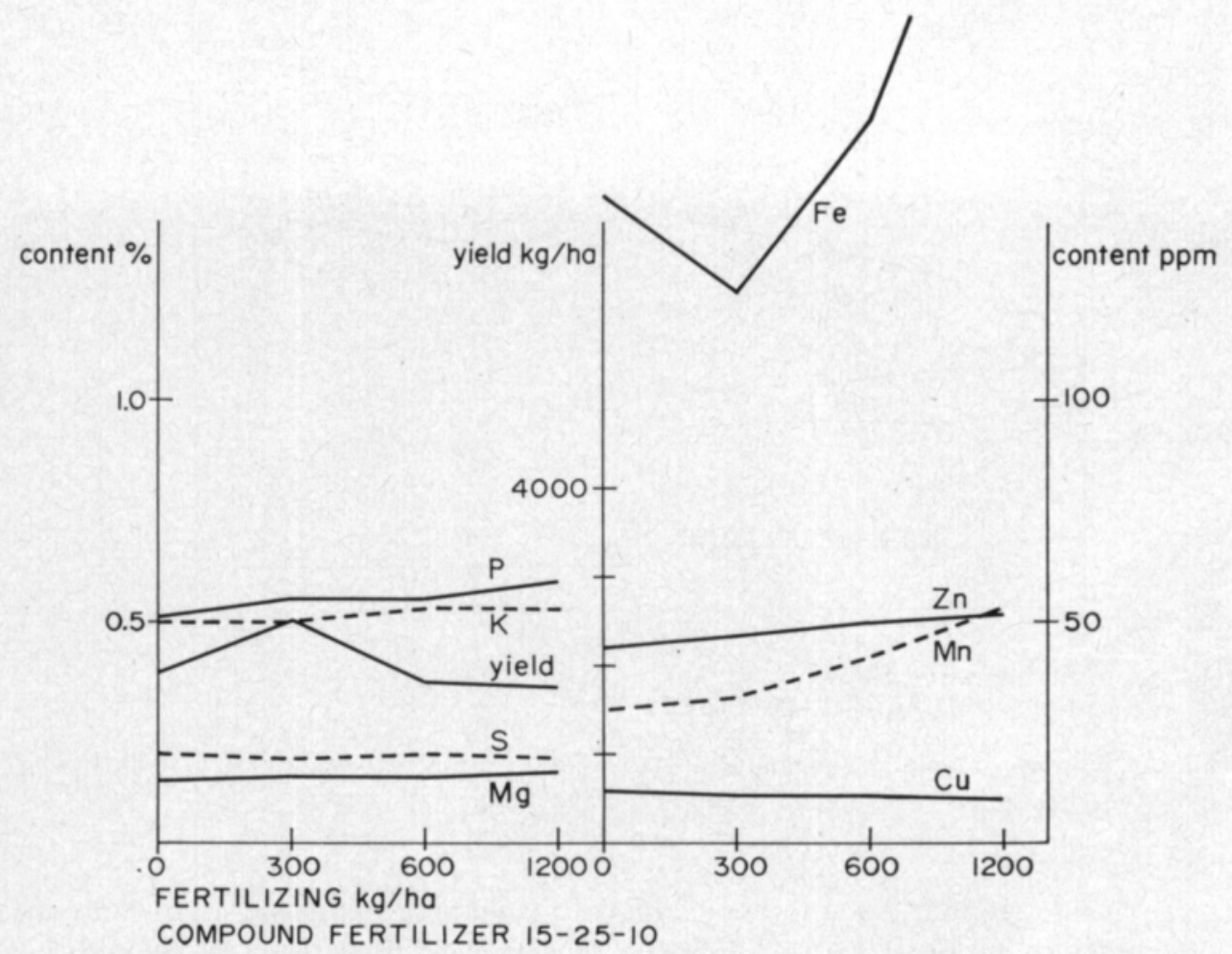

Fig. 3. Average contents of some minerals in barley on dry weight basis and yield when grown in peat soil at Leteensuo during 1972.

Yields of barley grown in peat soil remained very low $(2000 \mathrm{~kg} / \mathrm{ha})$ irrespective of fertilization (Fig. 3). With the exception of manganese and iron, the level of other minerals in barley remained unchanged regardless of the level of fertilization. The composition of the fertilizers did not appear to influence the mineral content of barley either (Fig. 4 and 5).

Observing the results attention is mainly drawn to the content level of the minerals and to its variations. Comparison with the investigation of LAKANEN (1969) concerning Finnish spring wheat and rye shows that the contents of most minerals are exactly on the same level. The greatest exeptions are to be found in the contents of strontium and nickel. Only half as much $\mathrm{Sr}$ was present in this investigation and the amount of $\mathrm{Ni}$ was clearly larger than that stated by LAKAnEN. The contents of $\mathrm{Fe}, \mathrm{Cu}, \mathrm{Mn}, \mathrm{Zn}$ and $\mathrm{Mg}$ presented by KoIvistoinen (1971) are within the variation limits (Table 1) of this investigation. When compared to the Swedish cereals the contents of most minerals are on the same level or higher than those noted by Svanberg (1971).

Variations in the mineral contents among small grains depend greatly on the soil. NPK-fertilization or the increased yield thus obtained has not essentially affected the contents of minerals, at least not by reducing them.

Since an increase in yield has not reduced the contents of minerals in cereal grain, it seems clear that a high yield consumes a lot of trace elements. Seen 
against this background it is understandable that the yield level can have a marked effect on the rapidity of exhaustion of the soil's trace element sources necessitating compensating fertilization increases.

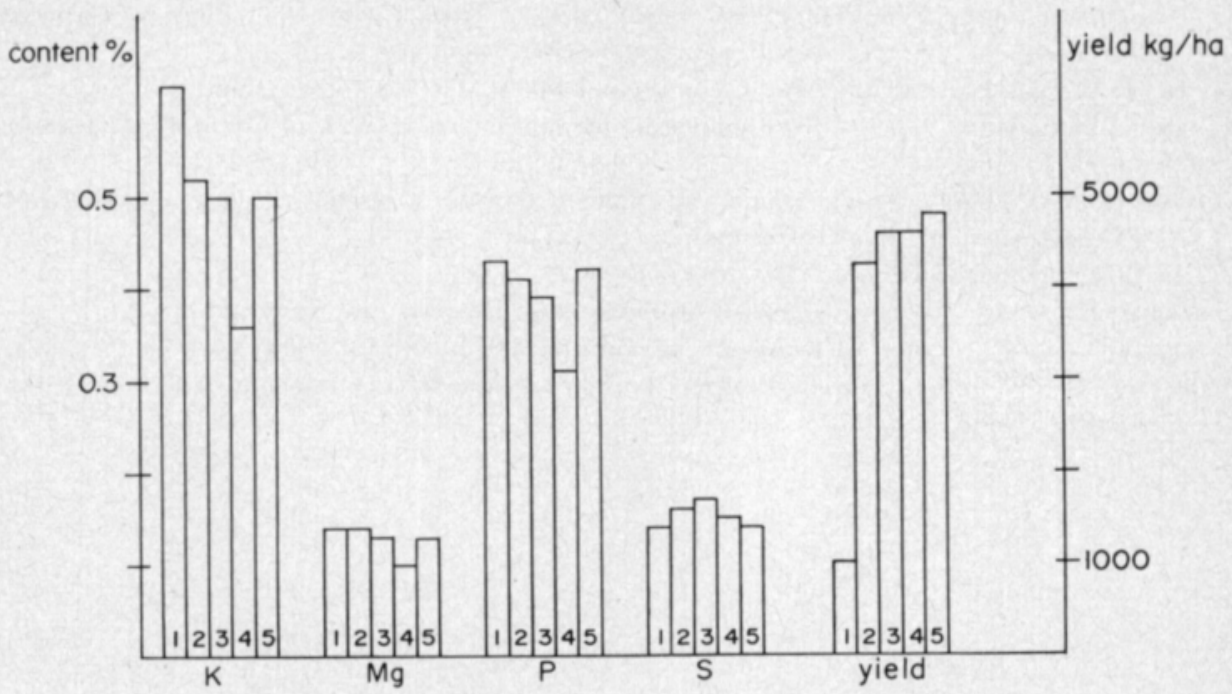

Fig. 4. Effect of type of fertilization on content of some minerals and yield of barley in clay soil at Kotkaniemi in 1972.

1. Without fertilization

2. Calcium ammonium nitrate $(100 \mathrm{~kg} \mathrm{~N} / \mathrm{ha})$

3. Compound fertilizer $20-10-10(100 \mathrm{~kg} \mathrm{~N} / \mathrm{ha})$

4.

$$
15-25-10
$$

$10-25-25$

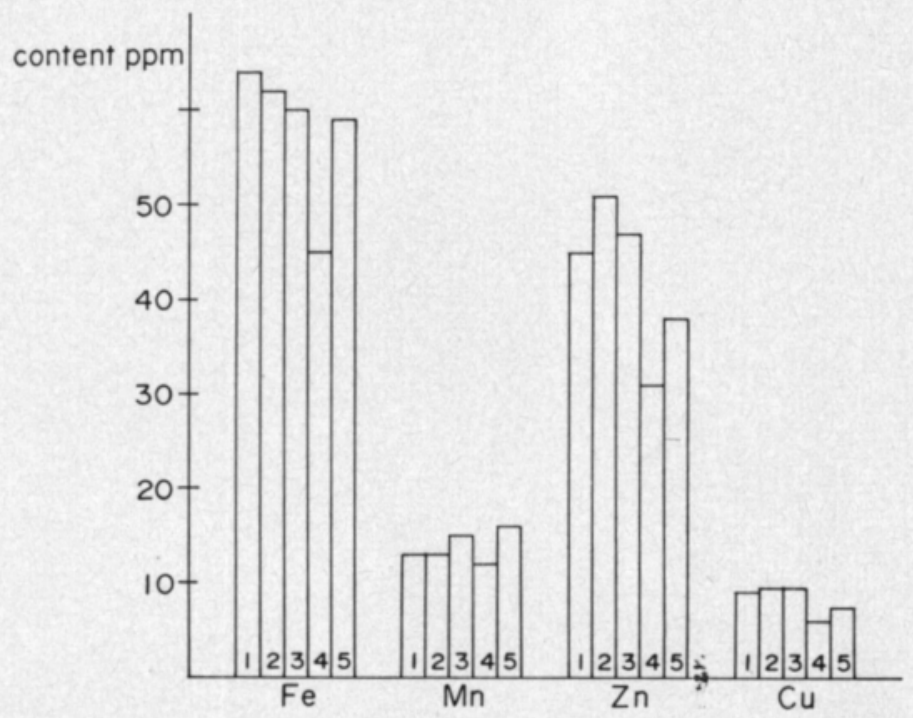

Fig. 5. (Continuation to Fig. 4). Effect of type of fertilization on content of some minerals in barley in clay soil at Kotkaniemi in 1972. Symbols $1-5$ as in Fig. 4. 


\title{
REFERENCES
}

ARnon, I. 1966. Quality criteria of agricultural produce and the influence of mineral on quality 1966. Mimeogr. 92 p. (Available at International Potash Institute, Berne).

Burridge, J. C. 1972. Seasonal Uptake and Distribution of Trace Elements in Cereals. (Agriculture Group Symposium 15th February 1972 Trace Elements in Plant and Animal Nutrition) J. Sci. Fd. Agric. $23: 789-799$.

GaUCH, H. G. 1972. Inorganic Plant Nutrition. 488 p. 1st Ed. Stroudsburg.

KerÄnen, T. \& TAInio, A. 1967. Kali-magnesiumlannoituskokeen tuloksia. Maatal. ja Koetoim. 18: 9-15.

Korvistornen, P. 1971. Viljan asema valtakunnan elintarvikehuollossa. Symposiumi Leipä 70 alustukset. p. $6-21$. Helsinki.

- - 1972, Hivenalkuaineet. Duodecim 88: 1525-1528.

LAKANEN, E. 1969. Viljan kivennäiskoostumuksesta. Koetoim. ja Käyt. 26, 8: 31.

SAUChelli, V. 1969. Trace Elements in Agriculture. 248 p. 1st Ed. New York.

SvanberG, O. 1971. De svenska skördeprodukternas innehăll av växtnäringsämnen. Stat. Landbr. Kem. Lab. 37: 3-10.

\section{SELOSTUS}

\section{Viljasadon kivennäisainepitoisuuksista ja lannoituksen vaikutuksesta niihin.}

\author{
Yrjö Pessi, Jorma Syvälahti, Esko Saari ja Mikko Ylänen \\ Kemira Oy, Helsinki
}

Kotkaniemen koetilalla ja Leteensuon koeasemalla järjestettyjen eri viljojen lannoituskokeiden jyväsadoista on analysoitu 14 alkuaineen pitoisuudet. Kauran pitoisuudet ovat olleet useimmissa tapauksissa korkeimmat ja rukiin sekä syysvehnän alhaisimmat. NPK-lannoitus ei ole oleellisesti muuttanut hivenainepitoisuuksia satotason huomattavasta noususta huolimatta. 